\title{
Degradabilidade ruminal da matéria seca, da proteína bruta e da fração fibrosa de silagens de milho, de sorgo e de Brachiaria brizantha
}

\author{
[Ruminal degradability of dry matter, crud protein, and fiber fraction of silages of corn, sorghum, \\ and Brachiaria brizantha] \\ A.J.V.Pires ${ }^{1,7}$, R.A. Reis $^{2,7}$, G.G.P. Carvalho ${ }^{3}$, G.R. Siqueira ${ }^{4}$, T.F. Bernardes ${ }^{5}$, \\ A.C. Ruggieri ${ }^{2}$, M.T.P. Roth $^{6}$ \\ ${ }^{1}$ Universidade Estadual do Sudoeste da Bahia - Itapetinga, BA \\ ${ }^{2}$ Faculdade de Ciências Agrárias e Veterinárias - UNESP - Jaboticabal, SP \\ ${ }^{3}$ Aluno de pós-graduação - UFV - Viçosa, MG \\ ${ }^{4}$ Agência Paulista de Tecnologia dos Agronegócios - Colina, SP \\ ${ }^{5}$ Aluno de pós-graduação - FCAV-UNESP - Jaboticabal, SP \\ ${ }^{6}$ Aluna de graduação - FCAV-UNESP - Jaboticabal, SP \\ ${ }^{7}$ Pesquisador do $\mathrm{CNPq}$ \\ RESUMO
}

\begin{abstract}
Avaliou-se a degradação da matéria seca (MS), da proteína bruta (PB), da fibra em detergente neutro (FDN), da fibra em detergente ácido (FDA) e da hemicelulose das silagens de milho, de sorgo e de Brachiaria brizantha. Foram utilizados três novilhos Nelore, machos, fistulados no rúmen, com média de peso de 200kg. Em cada animal foram incubadas amostras das três silagens nos tempos de 0, 6, 12, 24, 36, 48, 72 e 96 horas. Para as degradabilidades potencial e efetiva da MS (taxa de passagem no rúmen de $5 \% / \mathrm{h}$ ), a silagem de milho foi a que apresentou valores mais altos, 80,1 e 56,7\%, respectivamente, seguida da silagem de sorgo, 73,0 e 45,3\%, e da silagem de Brachiaria, 60,8 e 33,7\%. Para a PB, o maior valor de degradabilidade foi verificado para a silagem de milho, 87,0\%, seguida das silagens de sorgo, $81,8 \%$, e de Brachiaria, 75,2\%. A degradabilidade da FDN foi maior para as silagens de milho e sorgo. Para FDA, a silagem de sorgo apresentou perfil de degradação menor que a silagem de milho. Os resultados sugerem melhor qualidade da silagem de milho, seguida pela do sorgo e pela de Brachiaria.
\end{abstract}

Palavras-chave: degradação, forragem, valor nutritivo, volumoso

\begin{abstract}
The experiment evaluated the degradation of the dry matter (DM), crude protein $(C P)$, neutral detergent fiber $(N D F)$, acid detergent fiber $(A D F)$, and hemicellulose of silages of corn, sorghum and Brachiaria brizantha. Three steers averaging $200 \mathrm{~kg}$ bw were rumen fistulated. In each animal, the three silages were incubated for 0, 6, 12, 24, 36, 48, 72, and 96 hours. For the potential degradability and the effective degradability (passage rate 5\%/h) the corn silage presented the highest values, 80.1 and $56.7 \%$, respectively, followed by the sorghum silage (73.0 and 45.3\%), and the Brachiaria silage (60.8 and 33.7\%). For CP, the highest degradability value was also verified for the corn silage (87.0\%), followed by the sorghum silage (81.8\%), and Brachiaria silage (75.2\%). For NDF, the highest degradability values were also verified for the corn and sorghum silages. However, for ADF, the sorghum silage presented degradation profile lower than the corn silage. The results suggest a better quality of the corn silage, followed by sorghum and Brachiaria silages.
\end{abstract}

Keywords: degradation, forage, nutritive value, roughage

Recebido em 30 de junho de 2008

Aceito em 22 de fevereiro de 2010

E-mail: aureliano@uesb.br 


\section{INTRODUÇÃO}

O armazenamento de forragem na forma de silagem é prática adotada para minimizar os problemas ocasionados pela estacionalidade de produção de forragem no Brasil. Diversas gramíneas têm se destacado para a produção de silagem, dentre elas o milho, o sorgo e as gramíneas perenes como o capim-elefante, Brachiaria brizantha e outras.

O milho, tradicionalmente, é a cultura mais utilizada para produção de silagem. Além de possuir composição bromatológica que preenche as exigências para confecção de uma boa silagem, proporciona boa fermentação microbiana (Nussio et al., 2001). Segundo Molina et al. (2003a), a cultura do sorgo vem crescendo e representa grande percentual da área cultivada para produção de silagem no Brasil (10 a $12 \%$ ). Grande parte desse crescimento advém da alta produção por hectare, do bom valor nutritivo e da tolerância a déficits hídricos ocasionais. Gramíneas perenes, como Brachiaria brizanta em razão de sua elevada produção, podem também ser utilizadas para obtenção de silagem, bem como para aproveitar o excedente produzido na época das chuvas.

A estimativa da degradação ruminal dos alimentos tem sido fundamental para avaliar a quantidade de nutrientes disponíveis para os microrganismos do rúmen e sua qualidade (Barbosa et al., 1998; Moreira et al., 2003). A degradabilidade in situ baseia-se na colocação de pequena quantidade de um determinado alimento em bolsa porosa não degradável e sua subsequente inserção (ou incubação) no conteúdo ruminal de animais canulados no rúmen (Molina et al., 2003a). Segundo Teixeira (1997), a técnica de sacos de náilon é considerada ideal para simular o ambiente ruminal dentro de determinado regime alimentar, apesar de o alimento não sofrer os efeitos de mastigação, da ruminação e do escape ruminal.

O objetivo do experimento foi avaliar a degradabilidade ruminal da matéria seca, da proteína bruta, da fibra em detergente neutro, da fibra em detergente ácido e da hemicelulose das silagens de milho, de sorgo e de Brachiaria brizantha.

\section{MATERIAL E MÉTODOS}

Utilizaram-se tambores de metal com dimensões de $0,80 \mathrm{~m}$ de altura por 0,50 de diâmetro para confecção de silagens de milho, de sorgo e de Brachiaria brizanta. Os cultivares de milho, AG 7575, e de sorgo, BR 700 (com presença de tanino no grão), foram cortados no estádio de grão semiduro e no de grão pastoso, respectivamente, e a Brachiaria foi colhida 45 dias após corte de uniformização, sem fazer prémurcha. Todo o material, armazenado por 60 dias, foi compactado para obter a densidade de $650 \mathrm{~kg}$ de material verde $/ \mathrm{m}^{3}$.

Três novilhos da raça Nelore, com média de peso de $200 \mathrm{~kg}$, canulados no rúmen e mantidos em regime de confinamento em baias individuais, foram alimentados com dietas constituídas das respectivas silagens de milho, de sorgo ou de Brachiaria brizantha, fornecidas ad libitum, e $1 \mathrm{~kg}$ de concentrado à base de milho, farelo de soja e mistura mineral.

Após 60 dias de armazenamento, os silos foram abertos e desprezados aproximadamente $20 \mathrm{~cm}$ da parte superior em razão da presença de fungos na silagem. Amostras das camadas mais baixas foram retiradas, homogeneizadas e pré-secas em estufa com ventilação forçada de ar regulada para $65^{\circ} \mathrm{C}$. A composição química das silagens (Tab. 1) foi analisada seguindo os procedimentos descritos em Silva e Queiroz (2005).

Tabela 1. Teores médios de matéria seca (MS), proteína bruta (PB), fibra em detergente neutro (FDN) e fibra em detergente ácido (FDA) das silagens de milho, de sorgo e de Brachiaria brizantha

\begin{tabular}{lccc} 
& \multicolumn{3}{c}{ Silagem } \\
\cline { 2 - 4 } & Milho & Sorgo & Brachiaria \\
\hline MS & 32,4 & 31,9 & 28,7 \\
PB $^{1}$ & 8,1 & 9,3 & 9,5 \\
FDN $^{1}$ & 69,4 & 76,6 & 80,7 \\
FDA $^{1}$ & 36,6 & 38,7 & 53,1 \\
Hemicelulose & 32,8 & 37,9 & 27,6 \\
\hline 1\% & & &
\end{tabular}


Após a pré-secagem, as amostras das silagens foram moídas em moinhos dotados de peneiras com crivos de $4 \mathrm{~mm}$ e colocadas em sacos de náilon na quantidade de, aproximadamente, $3,0 \mathrm{~g}$ de matéria seca (MS)/saco, a fim de manter uma relação próxima de $20 \mathrm{mg}$ de $\mathrm{MS} / \mathrm{cm}^{2}$ de área superficial do saco. Os períodos de incubação corresponderam aos tempos de $0,6,12,24,36$, 48, 72 e 96 horas, sendo os sacos colocados em tempos diferentes para serem retirados todos ao mesmo tempo do rúmen.

Após o período de incubação, os sacos de náilon foram lavados em água corrente até que esta se apresentasse limpa, procedendo-se, então, à secagem. A determinação da MS foi feita em estufa regulada a $65^{\circ} \mathrm{C}$, por 72 horas. Os dados de degradabilidade in situ da matéria seca (DISMS) foram obtidos pela diferença observada entre as pesagens efetuadas antes e após a incubação ruminal e expressos em porcentagem.

O delineamento experimental utilizado foi o de parcelas subdivididas, em que os três animais representaram os blocos, as três silagens representaram os tratamentos e os sete tempos de incubação dos alimentos no rúmen, as subparcelas.

Por ser um modelo de crescimento assintótico de primeira ordem, que foi reparametrizado subdividindo o valor da assíntota em duas frações, "a" e "B", as taxas de degradação da MS e da proteína bruta (PB) foram calculadas utilizando-se a equação proposta por Ørskov e McDonald (1979): $\mathrm{D}_{\mathrm{t}}=\mathrm{a}+\mathrm{B}\left(1-\mathrm{e}^{\text {-ct }}\right)$, em que: $\mathrm{D}_{\mathrm{t}}=$ fração degradada no tempo " $\mathrm{t}$ " $(\%)$, " $\mathrm{a}$ " = fração solúvel $(\%)$; "B" = fração insolúvel potencialmente degradável $(\%)$; "c" = taxa de degradação da fração "B" (/h); e "t" = tempo (h).

A degradação da FDN, da FDA e da hemicelulose foi interpretada utilizando-se o modelo de Mertens e Loften (1980): $\mathrm{R}_{\mathrm{t}}=\mathrm{B} * \mathrm{e}^{-\mathrm{ct}}+$ $\mathrm{I}$, em que: $\mathrm{R}_{\mathrm{t}}=$ fração degradada no tempo " $\mathrm{t}$ " $(\%)$; I = fração indegradável; e "B", c"” e " $\mathrm{t}$ " como definidas anteriormente.
Procedeu-se à padronização de frações, segundo a proposição de Waldo et al. (1972), conforme equações: $\mathrm{B}_{\mathrm{P}}=\mathrm{B} /(\mathrm{B}+\mathrm{I}) * 100 ; \mathrm{I}_{\mathrm{P}}=\mathrm{I} /(\mathrm{B}+\mathrm{I}) * 100$; $\mathrm{I}=100-(\mathrm{a}+\mathrm{b})$, em que: $\mathrm{B}_{\mathrm{P}}=$ fração potencialmente degradável padronizada $(\%) ; \mathrm{I}_{\mathrm{P}}=$ fração indegradável padronizada $(\%)$; $\mathrm{B}$ e $\mathrm{I}=$ como definidas anteriormente.

Os parâmetros não-lineares "a", "B" e "c" foram estimados por meio de procedimentos iterativos de quadrados mínimos. As degradabilidades efetivas (DE) da MS e da PB no rúmen foram calculadas utilizando-se o modelo: $\mathrm{DE}=\mathrm{a}+(\mathrm{B} *$ $\mathrm{c} / \mathrm{c}+\mathrm{k})$, em que: $\mathrm{k}$ corresponde à taxa de passagem das partículas no rúmen, de acordo com o ARC (The nutrient..., 1984).

Para a DE da FDN, da FDA e da hemicelulose, utilizou-se o modelo: $\mathrm{DE}=\mathrm{B}_{\mathrm{P}}{ }^{*} \mathrm{c} /(\mathrm{c}+\mathrm{k})$, em que $\mathrm{B}_{\mathrm{P}}$ é a fração potencialmente degradável (\%) padronizada.

\section{RESULTADOS E DISCUSSÃO}

Os coeficientes da fração solúvel "a", da fração insolúvel potencialmente degradável "B", da fração não degradável "I" e da taxa de degradação "c" podem ser observados na Tab. 2, $\mathrm{e}$ as degradabilidades potencial e efetiva na Tab. 3.

Segundo Tonani et al. (2001), o desaparecimento da fração "a" caracteriza a solubilização dos açúcares e compostos nitrogenados solúveis remanescentes da fermentação no silo, constituída, principalmente, de sacarose, frutose, glicose e pequenas quantidades de manose e galactose. Em relação à MS, verificou-se maior valor da fração "a" para silagem de milho $(38,5 \%)$ seguido da silagem de sorgo $(21,4 \%)$ e da silagem de Brachiaria brizantha (12,5\%). Possivelmente a silagem de milho apresentava maior teor de açúcar residual, o que lhe conferiu maior fração "a" em relação às silagens de sorgo e Brachiaria brizantha. Para a fração "B", os valores encontrados foram, respectivamente, de $43,6,52,5$ e 48,3\% na mesma ordem de citação das silagens. 
Tabela 2. Parâmetros da degradação ruminal da matéria seca (MS), proteína bruta (PB), fibra em detergente neutro (FDN), fibra em detergente ácido (FDA) e hemicelulose (HEM) das silagens de milho, sorgo e Brachiaria incubadas no rúmen

\begin{tabular}{|c|c|c|c|c|c|}
\hline \multirow[b]{2}{*}{ Silagem } & \multicolumn{4}{|c|}{ Parâmetro } & \multirow{2}{*}{$\mathrm{R}^{2}$} \\
\hline & $\mathrm{a}(\%)$ & $\mathrm{B}(\%)$ & I (\%) & $\mathrm{c}(/ \mathrm{h})$ & \\
\hline & \multicolumn{4}{|c|}{ MS } & \\
\hline Milho & 38,5 & 43,6 & 17,9 & 0,036 & 99,5 \\
\hline Sorgo & 21,4 & 52,5 & 26,1 & 0,042 & 98,7 \\
\hline \multirow[t]{2}{*}{ Brachiaria } & 12,5 & 48,3 & 39,2 & 0,039 & 98,2 \\
\hline & \multicolumn{4}{|c|}{ PB } & \\
\hline Milho & 38,4 & 48,6 & 13,0 & 0,040 & 98,5 \\
\hline Sorgo & 30,3 & 51,5 & 18,2 & 0,049 & 98,2 \\
\hline \multirow[t]{2}{*}{ Brachiaria } & 23,7 & 51,5 & 24,8 & 0,044 & 98,7 \\
\hline & \multicolumn{4}{|c|}{ FDN } & \\
\hline Milho & - & 71,9 & 28,1 & 0,051 & 99,5 \\
\hline Sorgo & - & 66,6 & 33,4 & 0,047 & 98,6 \\
\hline \multirow[t]{2}{*}{ Brachiaria } & - & 57,5 & 42,5 & 0,036 & 97,9 \\
\hline & \multicolumn{4}{|c|}{ FDA } & \\
\hline Milho & - & 61,5 & 38,5 & 0,038 & 97,4 \\
\hline Sorgo & - & 49,7 & 50,3 & 0,024 & 91,8 \\
\hline \multirow[t]{2}{*}{ Brachiaria } & - & 48,6 & 51,4 & 0,035 & 92,4 \\
\hline & \multicolumn{4}{|c|}{ HEM } & \\
\hline Milho & - & 79,0 & 21,0 & 0,098 & 97,8 \\
\hline Sorgo & - & 81,5 & 18,5 & 0,075 & 96,7 \\
\hline Brachiaria & - & 75,0 & 25,0 & 0,028 & 91,1 \\
\hline
\end{tabular}

Tabela 3. Degradabilidades potencial (DP) e efetivas da matéria seca (MS), da proteína bruta (PB), fibra em detergente neutro (FDN), fibra em detergente ácido (FDA) e da hemicelulose (HEM) das silagens de milho, sorgo e Brachiaria calculadas para taxas de passagem no rúmen de 2,5 e $8 \% / \mathrm{h}$

\begin{tabular}{|c|c|c|c|c|}
\hline \multirow{2}{*}{ Silagem } & \multirow[b]{2}{*}{ DP } & \multicolumn{3}{|c|}{ Taxa de passagem $(/ \mathrm{h}))$} \\
\hline & & 0,02 & 0,05 & 0,08 \\
\hline & \multicolumn{4}{|c|}{ MS (\%) } \\
\hline Milho & 82,1 & 66,5 & 56,7 & 52,0 \\
\hline Sorgo & 73,0 & 56,9 & 45,3 & 39,4 \\
\hline \multirow[t]{2}{*}{ Brachiaria } & 60,8 & 44,5 & 33,7 & 28,4 \\
\hline & \multicolumn{4}{|c|}{$\mathrm{PB}(\%)$} \\
\hline Milho & 87,0 & 46,5 & 42,0 & 40,7 \\
\hline Sorgo & 81,8 & 66,9 & 55,8 & 49,9 \\
\hline \multirow[t]{2}{*}{ Brachiaria } & 75,2 & 59,1 & 47,8 & 42,0 \\
\hline & \multicolumn{4}{|c|}{ FDN (\%) } \\
\hline Milho & 71,9 & 51,65 & 36,21 & 27,99 \\
\hline Sorgo & 66,6 & 46,72 & 32,27 & 24,65 \\
\hline \multirow[t]{2}{*}{ Brachiaria } & 57,5 & 36,96 & 24,07 & 17,84 \\
\hline & \multicolumn{4}{|c|}{ FDA $(\%)$} \\
\hline Milho & 61,5 & 40,29 & 26,56 & 19,81 \\
\hline Sorgo & 49,7 & 27,11 & 16,12 & 11,47 \\
\hline \multirow[t]{2}{*}{ Brachiaria } & 48,6 & 30,93 & 20,01 & 14,79 \\
\hline & \multicolumn{4}{|c|}{ HEM (\%) } \\
\hline Milho & 79,0 & 65,61 & 52,31 & 43,49 \\
\hline Sorgo & 81,5 & 64,34 & 48,90 & 39,44 \\
\hline Brachiaria & 75,0 & 43,75 & 26,92 & 19,44 \\
\hline
\end{tabular}


A taxa de degradação "c" foi de $3,58 \% /$ h para a silagem de milho, $4,15 \% / \mathrm{h}$ para a silagem de sorgo e 3,91\%/h para a silagem de Brachiaria. Para a degradabilidade potencial da MS, os valores encontrados foram de 82,1; 73,9 e $60,8 \%$, respectivamente, para as silagens de milho, de sorgo e de Brachiaria brizantha. As diferenças observadas no potencial de degradação entre as silagens provavelmente estão relacionadas à própria composição química do material, uma vez que maiores teores de FDN foram observados para a silagem de Brachiaria, seguida das silagens de sorgo e milho (Tab. 1). Essas variações nas estimativas dos parâmetros de degradação das silagens podem ser atribuídas à presença de tanino na silagem de sorgo e pelo maior teor de umidade na silagem de Brachiaria brizantha.

Ainda, em relação à MS, os valores de degradabilidade efetiva encontrados foram de 56,$7 ; 45,3$ e $33,7 \%$, respectivamente, para as silagens de milho, de sorgo e de Brachiaria brizantha, considerando-se a taxa de passagem de $5 \%$. Os resultados obtidos para as silagens de milho e sorgo estão de acordo com Martins et al. (1999), que encontraram valores de degradabilidade efetiva de 54,8 e $46,0 \%$, respectivamente.

Sabe-se que o cultivar de sorgo utilizado no experimento para a produção de silagem contém tanino, o que pode ter contribuído para a menor degradabilidade da MS, pois, segundo Rabelo (1997), os taninos podem reduzir a degradabilidade da parede celular pela ligação com enzimas bacterianas. Esse fato foi observado por Molina et al. (2003b), quando verificaram menor valor de desaparecimento de MS após 96 horas de incubação da silagem de sorgo com tanino no grão (BR 700 e BR 701) em relação àquela sem tanino no grão (BR 303 e BR 304). Embora o milho tenha demonstrado maior potencial para degradação no período de 96 horas (Fig. 1), os valores observados para as silagens de milho e sorgo no presente trabalho são semelhantes aos valores de degradabilidades da MS $(74,4$ e $75,4 \%)$ para sorgo sem tanino apresentados pelos autores para o tempo de incubação de 96 horas. Provavelmente, a silagem de milho, por não apresentar fatores antinutricionais, como a presença de tanino, apresentou maior degradação da MS quando comparada às outras silagens.

Quanto às estimativas de degradação obtidas para a PB, observou-se a mesma tendência obtida para a MS, ou seja, a silagem de milho destacouse com maiores frações "a" e "B", seguida pela silagem de sorgo e Brachiaria (Fig. 2). Quanto à degradabilidade potencial da $\mathrm{PB}$, as silagens de milho e sorgo apresentaram valores superiores a $80 \%$ (Tab. 3). As estimativas de degradabilidade potencial obtidas no presente trabalho confirmam valores já obtidos por Campos et al. (2003).

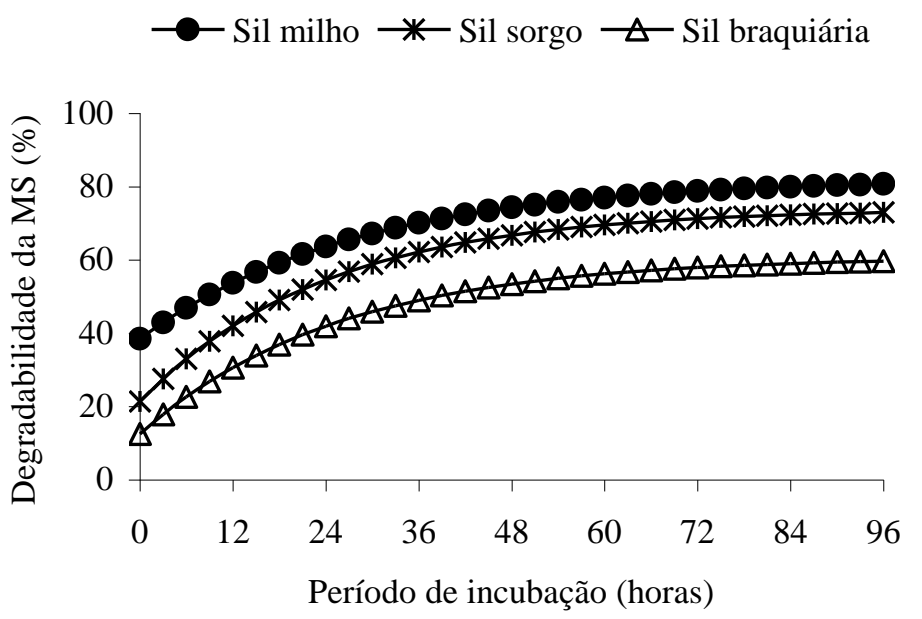

Figura 1. Degradabilidade da matéria seca (MS) de silagens de milho, de sorgo e de capim-braquiária (Brachiaria brizantha), em função do período de incubação (horas). 
O nível de utilização da fração nitrogenada é importante na avaliação de alimentos e na especificação de exigências nutricionais dos ruminantes (Rossi Júnior et al., 1997). A flora microbiana do rúmen transforma nitrogênio não proteico e proteico degradável em proteína microbiana, desde que disponha de energia. A disponibilidade de energia e nitrogênio para os microrganismos é determinada pelas taxas de degradação e passagem pelo rúmen, e influencia a eficiência e a quantidade de proteína microbiana sintetizada.

Quanto aos parâmetros de degradação ruminal da FDN (Fig. 3), observaram-se maiores valores para a silagem de milho, seguidos pelos de sorgo e de Brachiaria (Tab. 2). A mesma tendência foi observada quanto à FDA (Fig. 4). Dentre os resultados obtidos para os parâmetros "B" e "c", a silagem de milho destacou-se com valores mais altos seguidos pelos de sorgo e de Brachiaria.
Quanto ao FDA, observou-se o mesmo comportamento, com exceção da Brachiaria, a qual superou a silagem de sorgo.

Verificaram-se maiores degradabilidades potencial e efetiva da FDN para a silagem de milho, seguida pela de sorgo e pela de Brachiaria (Tab. 3). Contudo, para a FDA, a silagem de Brachiaria superou a do sorgo, que apresentou os menores valores de degradabilidade ruminal dessa fração. Em ruminantes, a maior parte da celulose é digerida no rúmen, enquanto considerável porção da hemicelulose escapa desse compartimento e é fermentada nos intestinos. Dessa forma, como a FDA é basicamente constituída de lignina e celulose, é possível que o tipo de celulose presente no sorgo, além da presença de tanino, tenha influenciado negativamente na degradação da FDA no rúmen, como verificado por Campos et al. (2003).

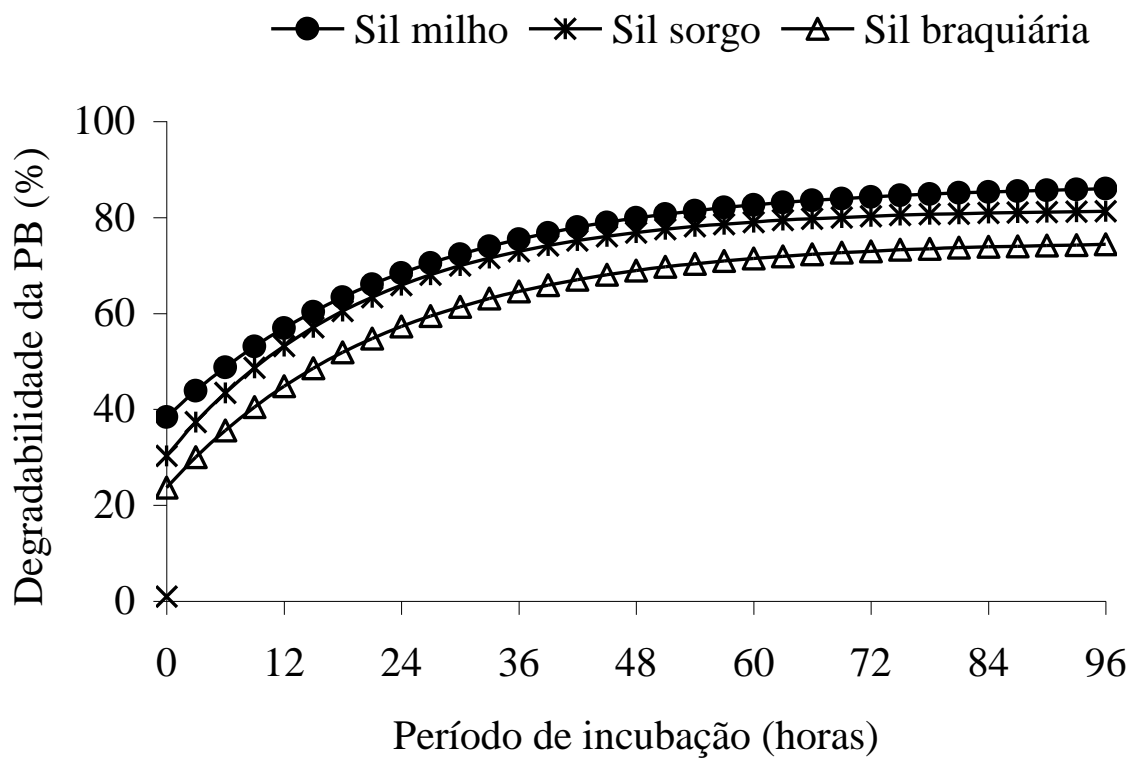

Figura 2. Degradabilidade da proteína bruta (PB) de silagens de milho, de sorgo e de capim-braquiária (Brachiaria brizantha), em função do período de incubação (horas).

Considerando diferentes genótipos de sorgo avaliados por vários autores (Rabelo, 1997; Serafim et al., 2000; Molina et al., 2002), verificou-se que, na maioria dos estudos, a perda da FDN no tempo zero foi entre 4 e $21 \%$. Em experimentos dessa natureza, a lavagem do material no tempo zero permite a perda de alguma porção do alimento teste pela porosidade dos saquinhos, levando a erros na estimação da fibra solúvel. No presente estudo, não foi observada solubilização da FDN no tempo zero. No entanto, uma pequena porção de FDN foi perdida no tempo zero pelo motivo citado, que foi corrigida de acordo com a proposição de Waldo et al. (1972). Não sendo a FDN solúvel em água (Stensig et al., 1994), pressupõe-se que 
quanto menor o valor encontrado em porcentagem para essa fração no tempo zero, maior a confiabilidade dos resultados. De qualquer forma, existem modelos específicos, como o proposto por Waldo et al. (1972), para as estimativas de degradação das frações fibrosas. A partir dos ajustes propostos por esses autores, é possível fazer uma padronização das frações fibrosas e dos componentes da parede celular, e evitar que inconsistências, como a estimação de fibra solúvel, possam ser cometidas.
Os taninos podem interferir na determinação e nos resultados da degradabilidade das frações fibrosas (Makkar et al., 1997), formando complexos com as proteínas e fibras, que são insolúveis em detergente (Makkar et al., 1997). Desse modo, tudo leva a crer que tal fato tenha ocorrido no presente trabalho, uma vez que o sorgo utilizado apresentou valor de degradabilidade mais baixo que o sorgo sem tanino estudado por Campos et al. (2003).

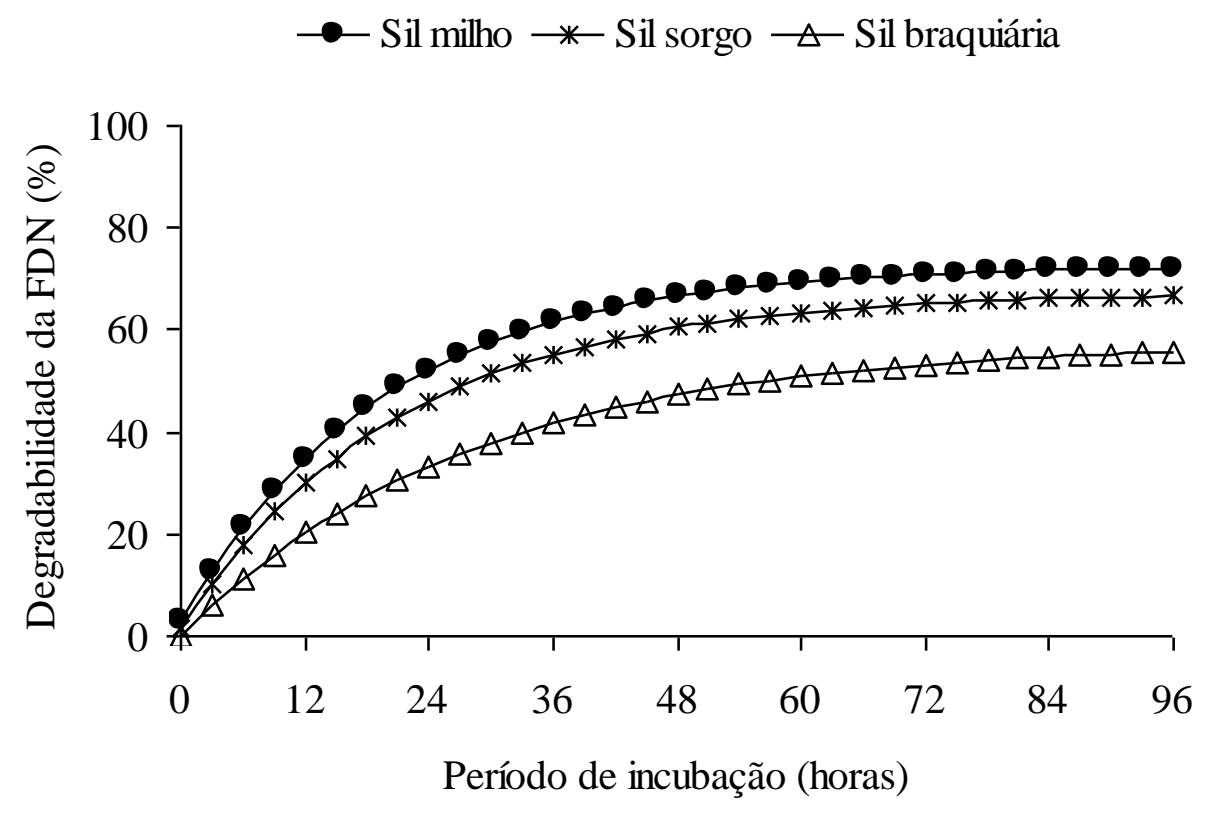

Figura 3. Degradabilidade da fibra em detergente neutro (FDN) de silagens de milho, de sorgo e de capim-braquiária (Brachiaria brizantha), em função do período de incubação (horas).

A fração insolúvel potencialmente degradável da hemicelulose na silagem de milho foi semelhante à da FDN (acima de 70\%). As silagens de sorgo e de Brachiaria também apresentaram valores acima de $70 \%$ da hemicelulose; entretanto, mais baixos valores foram observados, quanto à FDN com variação de 57 a $67 \%$.

Molina et al. (2002) observaram valor médio de $70,0 \%$ de degradação ruminal da hemicelulose de seis genótipos de sorgo para a fração insolúvel potencialmente degradável de sorgos com tanino. Esse valor é menor que o obtido para a silagem de sorgo no presente trabalho $(81,5 \%)$. Embora não mensurada em nenhum dos trabalhos, essa diferença pode estar relacionada com a concentração de taninos nos diferentes cultivares de sorgo utilizadas nos experimentos.

As silagens de sorgo e de Brachiaria brizantha apresentaram perfil de degradabilidade da FDA semelhante em todos os períodos de incubação (Fig. 4). A silagem de milho destacou-se pelos resultados mais altos. O máximo atingido pela silagem de milho foi de $61,5 \%$ para o tempo de 96 horas e de $49,7 \%$ e $48,6 \%$, para as silagens de sorgo e de Brachiaria, respectivamente (Tab. 3). 


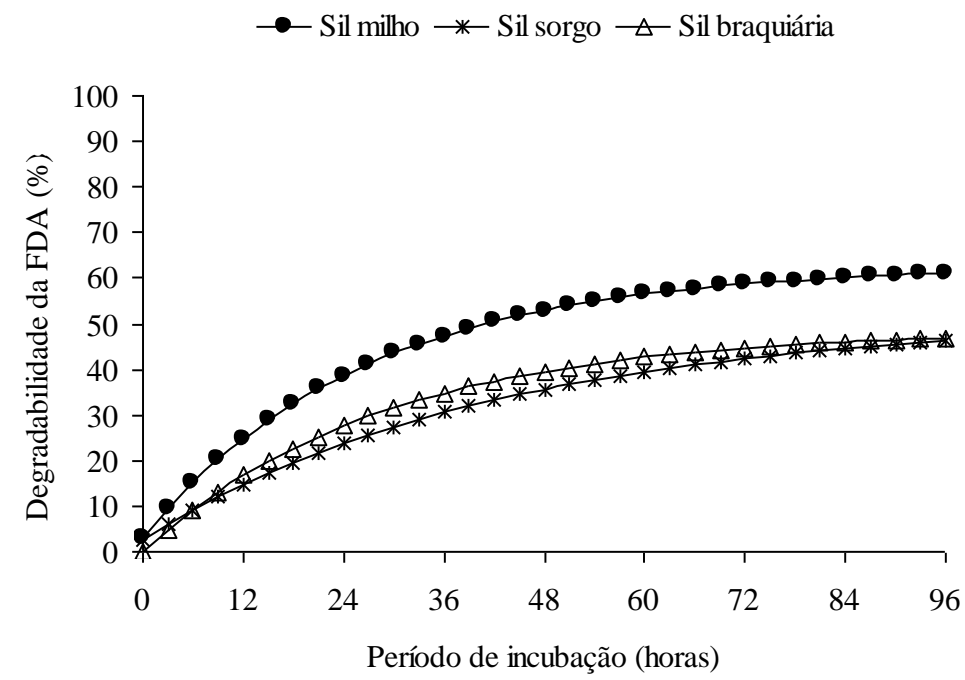

Figura 4. Degradabilidade da fibra em detergente ácido (FDA) de silagens de milho, de sorgo e de capimbraquiária (Brachiaria brizantha), em função do período de incubação (horas).

Segundo Ítavo et al. (2002), de todos os nutrientes necessários às exigências nutricionais para mantença, crescimento e produção de bovinos, a energia oriunda da degradação ruminal da celulose e da hemicelulose constitui a principal contribuição dos volumosos.

No caso da hemicelulose, as silagens de milho e de sorgo apresentaram rápida degradação dessa fração nas primeiras horas após a incubação ruminal, e a silagem de sorgo maior taxa de degradação a partir do tempo de incubação de 24 horas (Fig. 5), o qual apresentou maior potencial de degradação. A degradabilidade potencial da hemicelulose na silagem de sorgo foi de $81,5 \%$, seguida das silagens de milho, 79,0\%, e de Brachiaria, 75,0\%. Embora a silagem de Brachiaria tenha apresentado degradação inicial mais lenta, verificou-se que, nos últimos tempos de incubação, as silagens de milho e de Brachiaria apresentaram valores semelhantes (Fig. 5). Como a hemicelulose é uma importante fonte de energia para os ruminantes, estes resultados indicam que a hemicelulose da silagem de milho é disponibilizada mais rapidamente para a microflora ruminal.

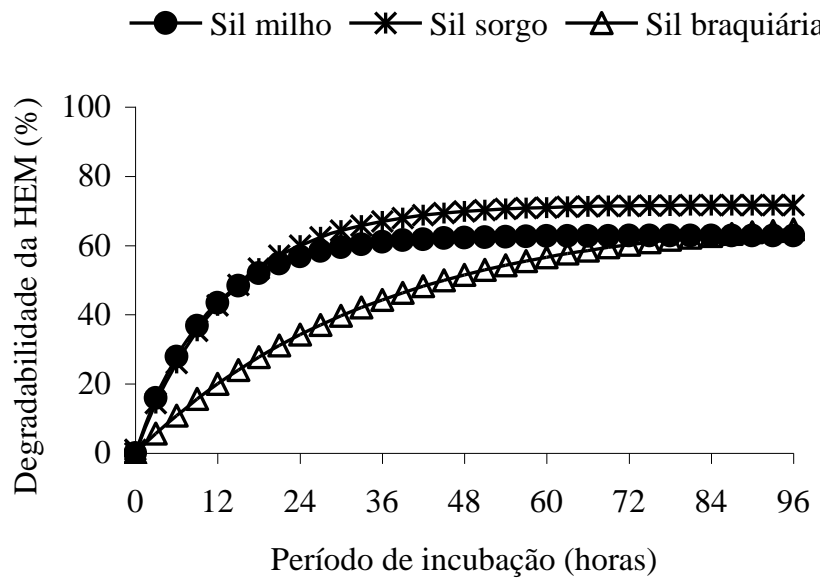

Figura 5. Degradabilidade da hemicelulose (HEM) de silagens de milho, de sorgo e de capim-braquiária (Brachiaria brizantha), em função do período de incubação (horas). 


\section{CONCLUSÕES}

A silagem de milho apresenta maiores degradabilidades potencial e efetiva da matéria seca, da proteína bruta, da fibra em detergente neutro, da fibra em detergente ácido e da hemicelulose que as silagens de sorgo e de Brachiaria brizantha, e a silagem de sorgo maior que a de Brachiaria. Embora a silagem de Brachiaria brizantha mostre valores mais baixos, a ensilagem do excedente de produção dessa gramínea constitui uma alternativa interessante, uma vez que apresenta bons resultados de degradação ruminal.

\section{REFERÊNCIAS BIBLIOGRÁFICAS}

BARBOSA, G.S.S.C.; SAMPAIO, I.B.M.; GONÇALVES, L.C. Fatores que afetam os valores de degradabilidade in situ da matéria seca de forrageiras tropicais: I. dieta basal. Arq. Bras. Med. Vet. Zootec., v.50, p.731-735, 1998.

CAMPOS, W.E.; SATURNINO, H.M.; SOUSA, B.M. et al. Degradabilidade in situ da silagem de quatro genótipos de sorgo com e sem tanino. II Fibra detergente neutro, fibra detergente ácido, hemicelulose e celulose. Arq. Bras. Med. Vet. Zootec., v.55, p.450-453, 2003.

ÍTAVO, L.C.V.; VALADARES FIHO, S.C.; SILVA, F.F. et al. Consumo, degradabilidade ruminal e digestibilidade aparente de fenos de gramíneas do gênero Cynodon e rações concentradas utilizando indicadores internos. Rev. Bras. Zootec., v.31, supl., p.1024-1032, 2002.

MAKKAR, H.P.S.; BLUMMEL, M.; BECKER, $\mathrm{K}$. In vitro rumen apparent and true digestibilities of tannin rich forages. Anim. Feed Sci. Technol., v.67, p.245-251, 1997.

MARTINS, A.S.; ZEOULA, L.M.; PRADO, I.N. et al. Degradabilidade ruminal in situ da matéria seca e proteína bruta das silagens de milho e sorgo e de alguns alimentos concentrados. Rev. Bras. Zootec., v.28, p.1109-1117, 1999.

MERTENS, D.R.; LOFTEN, J.R. The effect of starch on forage fiber digestion kinectis in vitro. J. Dairy Sci., v.63, p.1437-1446, 1980.
MOLINA, L.R.; GONÇALVES, L.C.; RODRIGUEZ, N.M. et al. Degradabilidade in situ das frações fibrosas de silagens de seis genótipos de sorgo (Sorghum bicolor L. Moench) em diferentes estádios de maturação. Arq. Bras. Med. Vet. Zootec., v.54, p.169-179, 2002.

MOLINA, L.R.; RODRIGUEZ, N.M.; GONÇALVES, L.C. et al. Efeito do tanino na degradabilidade in situ da matéria seca e da proteína bruta de seis genótipos de sorgo (Sorghum bicolor (L.) Moench) ensilados no estádio de grão pastoso. Arq. Bras. Med. Vet. Zootec., v.55, p.203-208, 2003a.

MOLINA, L.R.; RODRIGUEZ, N.M.; SOUSA, B.M. et al. Parâmetros de degradabilidade potencial da matéria seca e da proteína bruta das silagens de sorgo (Sorghum bicolor (L.) Moench), com e sem tanino no grão, avaliados pela técnica in situ. Rev. Bras. Zootec., v.32, p.222-228, 2003b.

MOREIRA, J.F.C.; RODRIGUEZ, N.M.; FERNANDES, P.C.C. et al. Concentrados proteicos para bovinos. 1. Digestibilidade in situ da matéria seca e da proteína bruta. Arq. Bras. Med. Vet. Zootec., v.55, p.315-323, 2003.

NUSSIO, L.G.; CAMPOS, F.P.; DIAS, F.N. Importância da qualidade da porção vegetativa no valor alimentício da silagem de milho. In: SIMPÓSIO SOBRE PRODUÇÃO E UTILIZAÇÃO DE FORRAGENS CONSERVADAS. 1., 2001, Maringá. Anais... Maringá: UEM, 2001. p.319.

ØRSKOV, E.R.; McDONALD, I. The estimation of protein degradability in the rúmen fron incubation weighted according to rate of passage. J. Agric. Sci., v.92, p.499-503, 1979.

RABELO, E. Degradabilidade in situ de silagens de híbridos de sorgo (Sorghum bioclor (L) Moench) de porte médio com diferentes teores de taninos e suculência no colmo. 1997. 98f. Dissertação (Mestrado) - Escola de Veterinária, Universidade Federal de Minas Gerais, Belo Horizonte.

ROSSI JÚNIOR, P.; BOSE, M.L.V.; BOIN, C. et al. Degradabilidade ruminal do amido de silagem de milho, farelo de soja e sorgo grão, em bovinos da raça nelore. Rev. Bras. Zootec., v.26, p.416-422, 1997. 
SERAFIM, M.V.; BORGES, I.; GONÇALVES, L.C. et al. Desaparecimento in situ da matéria seca, proteína bruta e fração fibrosa das silagens de híbridos de sorgo. Arq. Bras. Med. Vet. Zootec., v.52, p.634-640, 2000.

SILVA, D.J.; QUEIROZ, A.C. Análise de alimentos (métodos químicos e biológicos). Viçosa: Universidade Federal de Viçosa, 2005. $235 \mathrm{p}$

SISTEMA de análises estatísticas e genéticas SAEG. Viçosa, MG: UFV, 2000. 301p.

STENSIG, T.; WEISBJERG, M.R.; HVELPLUND, T. Estimation of ruminal digestibility of NDF from in sacco degradation and rumen fractional outflow rate. Acta Agric. Scand., v.44, p.96-109, 1994.
TEIXEIRA, J.C. Introdução aos métodos de determinação de digestibilidade em ruminantes. In: TEIXEIRA, J.C. (Ed.). Digestibilidade em ruminantes. Lavras: UFLA/FAEP, 1997. p.7-27.

THE NUTRIENT requirements of ruminant livestock. Farnham Royal: CAB, 1984. Suppl., $45 \mathrm{p}$.

TONANI, F.L.; RUGGIERI, A.C.; QUEIROZ, A.C. et al. Degradabilidade ruminal in situ da matéria seca e da fibra em detergente neutro em silagens de híbridos de sorgo colhidos em diferentes épocas. Arq. Bras. Med. Vet. Zootec., v.53, p.100-104, 2001.

WALDO, D.R.; SMITH, L.W.; COX, E.L. Model f cellulose disappearance from the rumen. J. Dairy Sci., v.55, p.125-129, 1972. 